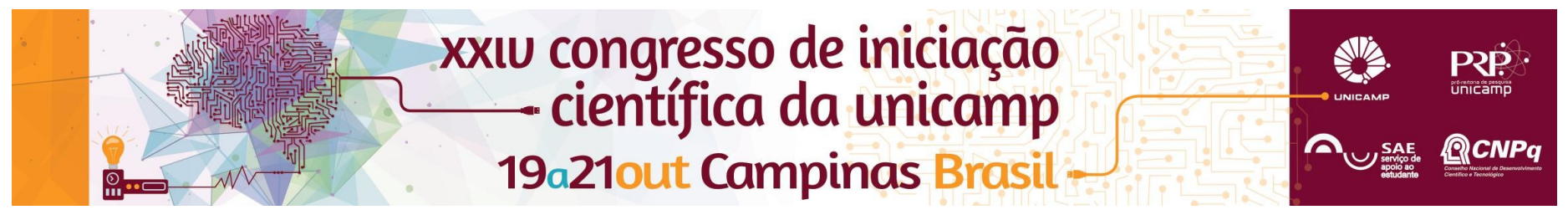

\title{
História em Quadrinhos no Ensino de História.
}

\section{Monique Prado Pinho (ID PIBID/CAPES), Vanessa L. Motoso *(ID PIBID/CAPES), Dayana de Oliveira Formiga (Orientador/ USP/ UNASP-Ec)}

\section{Resumo}

As Histórias em quadrinhos deve ser analisada como uma fonte artística. Dentro do âmbito escolar, no entanto ela pode ser utilizada como um recurso didático auxiliando no desenvolvimento da aprendizagem, bem como uma forma de se aproximar do saber histórico. Apesar de não se encaixar completamente em um padrão literário, permite de uma maneira simples e unificada, entre imagem e texto, que os educandos possam construir uma história crítica, reflexiva e problematizada.

\section{Palavras-chave:}

História em quadrinhos; Ensino de História; Metodologias de Ensino

\section{Introdução}

Essa pesquisa apresenta discussões sobre práticas educativas relacionadas a inserção das Histórias em quadrinhos na sala de aula, desenvolvida no grupo de pesquisa do PIBID no Centro Universitário Adventista de São Paulo (UNASP). O objetivo desse estudo foi debater propostas eficientes para a utilização da $\mathrm{HQ}$ como um recurso didático no desenvolvimento da aprendizagem, mais especificamente em como conhecer a linguagem dos quadrinhos, de forma visual e verbal, a escolha do material, sabendo que esse recurso artístico não é produzido com foco no ensino, sendo o papel do professor de extrema importância não apenas nessa primeira etapa de triagem, mas na aplicação em levar os alunos a interpretar de forma completa e crítica, ensinando-os essa outra linguagem que muito se difere das literaturas comuns. Auxiliar em projetos de interdisciplinaridade, envolvendo outras ciências como Geografia, Literatura, Português, História, Biologia, etc.

\section{Resultados e Discussão}

As Histórias em quadrinhos tiveram uma difícil abertura em relação ao público infantil e adolescente, já que a Associação Brasileira de Educadores (ABE) se posicionou fielmente contra essa ferramenta alegando que a mesma impressionava as crianças a terem hábitos estrangeiros. Quando na década de 1950 foi publicado o livro Seduction of the Innocent, onde um psiquiatra americano escreveu duras críticas a cultura de massa, para não sofrer censura oficial e tentar reverter um pouco a imagem negativa, foi criado um Código de Ética para as próximas publicações (SANTOS; VERGUEIRO, 2012). As Histórias em quadrinhos são uma expressão de arte, portanto não possuem compromisso com o ensino, elas devem ser utilizadas de maneira a complementar de uma forma dinâmica e diversificada o texto didático, se tornando uma grande aliada na aplicação dos conteúdos. Faz se necessário porem conhecer a linguagem, verbal e visual, empregada nas imagens, já que não constituem uma forma literária. Iniciando a triagem desde a escolha dos conteúdos, o material a ser utilizados, a faixa etária dos alunos, e o meio pelo qual a atividade será desenvolvida, pois sendo a interpretação uma parte fundamental da aprendizagem, também é indispensável que seja colocado de alguma maneira em prática. Essa fusão entre a imagem e o texto, contribui para a compreensão da vida de sociedades de diferentes tempos e espaços, proporcionando uma aproximação do saber histórico de uma maneira simples, estimulando não somente a leitura, mas o desenvolvimento de um senso crítico, levando a reflexão e problematização. Permitindo a percepção de diversas versões da história (SILVA JÚNIOR, RODRIGUES, 2013).

\section{Conclusões}

Dado o exposto, a relação estabelecida por essa pesquisa, é a importância da História em quadrinhos, como uma fonte artística para o ensino e aprendizagem, ressaltando assim a relevância de conhecer essa linguagem, na construção de uma História crítica, reflexiva e problematizada.

\section{Agradecimentos}

A Deus pela capacidade concedida para realizar esse estudo. Ao UNASP e o Curso de História. A nossa orientadora, Professora Me. Dayana Oliveira pelo esforço e dedicação em orientar essa pesquisa.

BONIFÁCIO, Selma de Fátima; CERRI, Luis Fernando. O ensino de história e as histórias em quadrinhos: algumas considerações. Disponível em:

$<$ http://www.pucpr.br/eventos/educere/educere2006/anais Evento/docs/CI-090-TC.pdf>. Acesso em 15 de julho de 2016.

GOMES, Ivan Lima. Uma breve introdução à história das histórias em quadrinhos no Brasil. Disponível em: < http://www.ufrgs.br/alcar/encontros-nacionais-

1/encontros-nacionais/6o-encontro-2008-/Uma\%20breve $\% 20$ introducao $\% 20$ a\%20historia\%20das\%20historias $\% 20$ em\%20quadrinhos\%20no\%20Brasil.pdf $>$. Acesso em: 15 de julho de 2016.

RODRIGUES, Fabiana Conceição de Moura Gonçalves, SILVA JÚNIOR, Astrogildo Fernandes. História em quadrinhos e Ensino e de História: olhares e práticas. Disponível em:

$<$ http://ojs.fe.unicamp.br/ged/FEH/article/view/6614/5495 $>$. Acesso em: 15 de julho de 2016.

SANTOS, R. E.; VERGUEIRO, W. Histórias em quadrinhos no processo de aprendizado: da teoria à prática. IN: EccoS, São Paulo, n. 27, p. 81-95. Jan. /abr. 2012. 